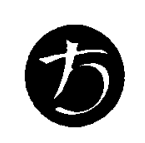

\title{
TUSCULUM-BÜCHEREI
}

Herausgeber: Dr. Hans Färber und Dr. Max Faltner 



\section{JULIUS CAESAR}

\section{D e r \\ B Ü R G E R K R I E G}

Lateinisch-deutsch ed. Georg Dorminger

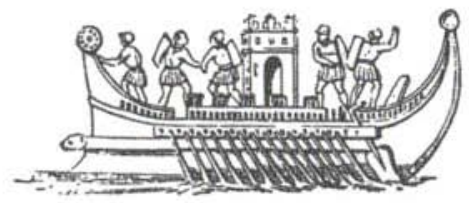


5. Auflage 1979

(C) Heimeran Verlag 1956

Alle Rechte vorbehalten einschließlich die der fotomechanischen Wiedergabe. Archiv 248 ISBN 3 7765 2014-0

Druck und Bindung: Sellier GmbH, Freising Printed in Gormany 